\title{
Pengaruh Pemberian Asam Alfa Lipoat terhadap Kadar Kolesterol Total pada Tikus Diabetes Melitus Tipe 2
}

\author{
Uli Kartika Lestari Sinaga, ${ }^{1 *}$ Ismawati, ${ }^{2}$ Enikarmila Asni ${ }^{2}$
}

\begin{abstract}
Hypercholesterolemia is complication in type 2 diabetes. Alpha lipoic acid (ALA) reduced total cholesterol by modulating cholesterol synthesis pathway and reduced cholesterol biosynthesis genes expression. The goal of this research was to investigate the prohibition of hypercholesterolemia in type 2 diabetes rat by ALA. Fifteen adult male wistar rats (23 months, 200-250 g body weight) were segregated into three groups (standard, type 2 diabetes and type 2 diabetes + ALA). Type 2 diabetes induced by streptozotocin $65 \mathrm{mg} / \mathrm{kg}$ and nicotinamide $110 \mathrm{mg} / \mathrm{kg}$. ALA was given for 3 weeks after type 2 diabetes induced.After 31 days total cholesterol of groups labelled is measured. The result showed there was significant difference between ALA and type 2 diabetes groups $(\mathrm{p}=0.012)$, and there was no significant difference between ALA and standard groups $(\mathrm{p}=0.591)$. As the conclusion, this study proves that ALA has effects on total cholesterol in type 2 diabetes rats.
\end{abstract}

Key Words: alpha lipoic acid, type 2 diabetes, total cholesterol

Diabetes melitus (DM) merupakan salah satu penyakit yang masih banyak di dunia. Prevalensi diabetes melitus tertinggi pada tahun 2015 adalah China dengan jumlah orang penderita DM adalah 109,6 juta orang, disusul oleh India dengan jumlah 69,2 juta orang lalu Amerika Serikat dengan jumlah 29,3 juta orang. ${ }^{1}$ Berdasarkan Riskesdas 2013 didapatkan prevalensi DM di Indonesia pada tahun 2013 adalah 1,5\% dari total penduduk Indonesia. ${ }^{2}$

Diabetes melitus merupakan salah satu penyakit yang memiliki angka kesakitan dan kematian yang tinggi dikarenakan banyaknya komplikasi yang timbul pada penderita $\mathrm{DM},{ }^{3}$ salah satu komplikasinya adalah dislipidemia. ${ }^{4}$ Keadaan dislipidemia seperti hiperkolesterolemia yang dapat memicu terjadinya proses inflamasi dan respon imun yang mempercepat pembentukan aterosklerosis. ${ }^{5}$ Aterosklerosis yang terjadi pada pembuluh darah jantung dapat menyebabkan terjadinya penyakit jantung koroner (PJK). ${ }^{6}$ Penyakit jantung koroner merupakan komplikasi yang menyebabkan angka kematian yang tinggi pada penderita DM. ${ }^{7}$

\footnotetext{
* Korespondensi : email : ulisinaga9896@yahoo.com

${ }^{1}$ Fakultas Kedokteran Universitas Riau

${ }^{2}$ KJF Biokimia Fakultas Kedokteran Universitas Riau
}

Tingginya angka kesakitan dan kematian pada penderita DM juga disebabkan oleh belum adanya pengobatan yang dapat menyembuhkan penyakit ini. ${ }^{8}$ Tatalaksana pada penderita DM saat ini terdiri dari 4 pilar yaitu edukasi, diet, obat-obatan dan latihan jasmani. ${ }^{9}$ Tatalaksana ini bertujuan untuk menjaga kadar gula darah pasien DM agar tetap dalam batas normal sehingga mencegah terjadinya komplikasi, tetapi tidak menyembuhkan penyakit DM. ${ }^{8}$

Penatalaksanaan penderita DM yang belum optimal mendorong dilakukannya berbagai penelitian untuk mengobati penyakit ini, salah satunya adalah penggunaan Alpha Lipoic Acid (ALA) atau asam alfa lipoat. Penelitian Maeda dan Xianwen tahun 2006 membuktikan bahwa ALA menurunkan kadar kolesterol total pada tikus diabetes sehingga mencegah risiko terbentuknya aterosklerosis dengan pemberian selama 20 minggu. ${ }^{10}$ Penelitian Ghelani dkk tahun 2017 juga menunjukkan perbedaan kadar kolesterol yang signifikan antara kelompok DM tanpa ALA dan kelompok DM yang diberikan ALA selama 4 minggu. ${ }^{11}$ Tetapi pada penelitian Salama tahun 2011 didapatkan hasil tidak ada penurunan kadar kolesterol total yang signifikan pada kelompok tikus yang diinduksi diabetes dengan streptozotosin dosis 
tunggal dan disertai pemberian ALA selama 30 hari dibandingkan dengan kelompok DM. ${ }^{12}$ Penelitian ini bertujuan untuk menganalisis pengaruh asam alfa lipoat terhadap kadar kolesterol total tikus DM tipe 2.

\section{METODE}

Penelitian ini merupakan penelitian eksperimental dengan desain post test only with control. Alat yang digunakan dalam penelitian ini adalah sonde lambung, tabung Eppendorf dan satu set alat glukosameter. Bahan yang digunakan adalah pakan tipe vivo 512, eter sebanyak 3-5 ml, heparin, streptozotosin, nikotinamid dan asam alfa lipoat.Tikus galur wistar (umur 2-3 bulan, berat badan 200-250 gram) diadaptasikan selama satu minggu, makan dan minum ad libitum. Tikus dibagi 3 kelompok yang masing-masing kelompok terdapat 5 tikus. Setiap kelompok akan mendapat perlakuan yang berbeda.

- Kelompok 1 yaitu kelompok kontrol yang hanya diberikan diet standar

- Kelompok 2 yaitu kelompok DM tipe 2 yang diberikan streptozotosin-nikotinamid sebagai induksi DM disamping diet standar

- Kelompok 3 yaitu kelompok DM tipe $2+$ ALA yang diberikan streptozotosin-nikotinamid dan ALA disamping diet standar
Induksi DM tipe 2 pada tikus dilakukan dengan metode streptozotosin-nikotinamid. Tikus dipuasakan selama 12 jam, lalu diberikan streptozotosin (Sigma 50130 ) intraperitoneal dengan dosis $50 \mathrm{mg} / \mathrm{kgBB}$, 15 menit kemudian diberikan nikotinamid (Supello 47865-U) intraperitoneal dengan dosis $110 \mathrm{mg} / \mathrm{kgBB}$. Setelah 6 jam diberikan glukosa $10 \%$ selama 24 jam untuk mencegah hipoglikemia. Tiga hari kemudian tikus dengan glukosa darah sewaktu $>250 \mathrm{mg} / \mathrm{dl}$ dimasukkan dalam kelompok DM tipe 2 atau DM tipe $2+$ ALA. ${ }^{13}$ Asam alfa lipoat (Sigma T5625) dengan dosis $60 \mathrm{mg} / \mathrm{kgBB}$ diberikan selama 3 minggu melalui sonde lambung pada kelompok DM tipe $2+$ ALA yaitu pada hari ke 10 sampai hari ke 31 perlakuan.Pengukuran kadar kolesterol total tikus dengan menggunakan metode CHOD-PAP (Enzimatic Photometric Test). Data hasil pengukuran kadar kolesterol yang diperoleh analisis dengan metode one way anova dan dilanjutkan dengan uji lanjut (post hot Test) yaitu uji LSD.

\section{HASIL DAN PEMBAHASAN}

Pada hari ke 32 dilakukan terminasi tikus dan dilakukan pengukuran kadar kolesterol total plasma tikus. Tabel. 1 menunjukkan bahwa nilai rata-rata kadar kolesterol total tikus galur Wistar, dari yang tertinggi sampai yang terendah berturut-turut adalah kelompok DM, kelompok kontrol dan kelompok ALA.

Tabel 1. Kadar kolesterol total tikus galur Wistar terhadap perlakuan(mg/dl)

\begin{tabular}{cccc}
\hline Ulangan & \multicolumn{3}{c}{ Perlakuan } \\
\cline { 2 - 4 } & Kontrol & DM & ALA \\
\hline 1 & 67 & 65 & 59 \\
2 & 55 & 82 & 62 \\
3 & 69 & 65 & 49 \\
4 & 60 & 70 & 52 \\
5 & 49 & 75 & 65 \\
Total & 300 & 357 & 287 \\
\hline Rata-Rata & 60 & 71,4 & 57,4 \\
\hline
\end{tabular}

Pada Tabel 2 dapat dilihat bahwa terdapat perbedaan yang bermakna pada kelompok DM terhadap kelompok kontrol dan kelompok ALA dan tidak terdapat perbedaan yang bermakna antara kelompok kontrol dan kelompok ALA. 
Tabel 2. Hasil uji LSD

\begin{tabular}{ll}
\hline \multicolumn{1}{c}{ Perlakuan } & Signifikansi \\
\hline Kontrol vs DM & $\mathrm{p}=0,032^{*}$ \\
Kontrol vs ALA & $\mathrm{p}=0,591$ \\
DM vs ALA & $\mathrm{p}=0,012^{*}$ \\
\hline
\end{tabular}

Keterangan:*terdapat perbedaan yang bermakna secara statistik $(\mathrm{p}<0,05)$

\section{Hiperkolesterolemia pada tikus Diabetes Melitus tipe 2}

Penelitian dengan menggunakan hewan coba berupa tikus yang diinduksi streptozotosinnikotinamid ini pertama kali diperkenalkan oleh Masiello dkk pada tahun 1998 dengan menggunakan tikus galur Wistar. ${ }^{14}$ Karakteristik yang muncul pada hewan coba yang diinduksi streptozotosinnikotinamid tergantung dari berbagai hal yaitu dosis streptozotosin dan nikotinamid, umur hewan, waktu pemberian nikotinamid setelah pemberian streptozotosin, dan rute administrasi streptozotosin. Dosis streptozotosin $45-65 \mathrm{mg} / \mathrm{kg}$ dan dosis nikotinamid $100-120 \mathrm{mg} / \mathrm{kg}$ adalah dosis yang sering digunakan karena menghasilkan kadar glukosa yang tinggi. ${ }^{13}$ Intoleransi glukosa diamati setelah diberikan glucose challenge pada tikus yang diinduksi. ${ }^{15}$ Pemberian glucose challenge pada tikus yaitu diberikan glukosa $10 \%$ selama 24 jam, hal ini juga berguna untuk mencegah hipoglikemia pada tikus akibat proses induksi. ${ }^{13}$

Karakteristik tikus DM tipe 2 ini didasarkan pada mekanisme perlindungan nikotinamid terhadap sel â pankreas dari efek sitotoksik streptozotosin. Adapun karakteristik dari tikus yang diinduksi streptozotosin-nikotinamid adalah keadaan hiperglikemia sedang yang stabil (150-180 mg/dl) dan tidak memerlukan insulin eksogen untuk bertahan hidup, penurunan jumlah sel â pankreas mencapai $40 \%$ dan penurunan sekresi insulin mencapai $60 \%$, intoleransi glukosa, insulin merespon terhadap pemberian sulfonilurea (glibenklamid), tikus mengalami polifagi dan polidipsi. ${ }^{16}$ Karakteristik tikus yang diinduksi streptozotosin-nikotinamid ini mirip dengan karakteristik DM tipe 2 pada manusia. ${ }^{13}$
Tikus yang telah diinduksi DM tipe 2 akan menunjukkan kelainan metabolisme yang disebabkan oleh intoleransi glukosa setelah 2-3 minggu. ${ }^{16}$ Pernyataan ini sesuai dengan hasil penelitian yang dilakukan, dikarenakan terjadi peningkatan kolesterol total pada tikus yang telah diinduksi DM tipe 2 setelah 3 minggu.

Keadaan hiperkolesterolemia pada DM disebabkan oleh adanya resistensi insulin. Resistensi insulin pada DM menyebabkan penurunan aktivitas enzim Lipoprotein lipase (LPL) pada otot dan jaringan adiposa serta peningkatan transfer asam lemak bebas dari jaringan adiposa perifer ke hati. Hal ini menyebabkan terjadinya peningkatan sintesis trigliserida dan peningkatan sekresi Apo B yang akan meningkatkan produksi kolesterol VLDL. Peningkatan kadar kolesterol VLDL dan trigliserida akan menyebabkan penurunan HDL karena peningkatan hidrolisis HDL dan peningkatan small dense LDL karena peningkatan hidrolisis LDL. ${ }^{17}$

Hasil penelitian didapatkan adanya perbedaan kadar kolesterol pada kelompok kontrol dan pada kelompok DM. Pada Tabel 1 dapat dilihat bahwa rata-rata kadar kolesterol total pada kelompok kontrol adalah $60 \mathrm{mg} / \mathrm{dl}$ sedangkan pada kelompok DM didapatkan rata-rata kadar kolesterol yang lebih tinggi yaitu 71,4 mg/dl. Pada Tabel 2 didapatkan hasil uji statistik (post hoc test) terhadap kedua kelompok tersebut didapatkan perbedaan yang signifikan atau bermakna diantara kedua kelompok.

Beberapa penelitian lain juga menunjukkan terjadinya peningkatan kadar kolesterol total pada tikus dengan model induksi streptozotosinnikotinamid seperti pada penelitian Murugan dkk tahun 2006 menggunakan metode induksi 
streptozotosin-nikotinamid dengan dosis streptozotosin $65 \mathrm{mg} / \mathrm{kgBB}$ dan dosis nikotinamid 110 $\mathrm{mg} / \mathrm{kgBB}$ pada tikus wistar jantan yang diberi diet standar didapatkan peningkatan signifikan pada kadar kolesterol total tikus kelompok DM dibandingkan dengan kelompok kontrol setelah 45 hari. ${ }^{18}$ Penelitian Satheesh dkk pada tahun 2008 juga mendapatkan hasil yang sama dengan penelitian ini yaitu dengan menggunakan metode induksi streptozotosin-nikotinamid dengan dosis $65 \mathrm{mg} / \mathrm{kgBB}$ dan dosis nikotinamid $110 \mathrm{mg} / \mathrm{kgBB}$ pada tikus wistar jantan yang diberikan diet standar didapatkan peningkatan signifikan pada kadar kolesterol total tikus kelompok DM dibandingkan kelompok kontrol setelah 6 minggu. ${ }^{19}$

Pada tikus tersebut juga dilakukan pemeriksaan patologi anatomi untuk melihat lesi aterosklerosis pada aorta abdominalis oleh Ismawati dkk dan didapatkan adanya pembentukan lesi aterosklerosis pada kelompok DM. ${ }^{20}$ Maka dapat disimpulkan bahwa peningkatan kadar kolesterol total menyebabkan terbentuknya lesi aterosklerosis pada aorta abdominalis pada tikus kelompok DM.

\section{Pengaruh pemberian asam alfa lipoat}

Hasil penelitian didapatkan adanya perbedaan kadar kolesterol total pada kelompok DM dan pada kelompok ALA. Pada Tabel 1 dapat dilihat bahwa rata-rata kadar kolesterol total pada kelompok adalah 71,4 mg/dl sedangkan pada kelompok ALA didapatkan rata-rata kadar kolesterol yang lebih rendah yaitu 57,4 mg/dl. Pada Tabel 2 didapatkan hasil uji statistik (post hoc test) terhadap kedua kelompok tersebut dan didapatkan ada perbedaan yang signifikan atau bermakna diantara kedua kelompok. Maka dapat disimpulkan bahwa ALA dapat mencegah terjadinya hiperkolesterolemia pada tikus tersebut.

Berdasarkan uji statistik didapatkan tidak adanya perbedaan yang bermakna antara kelompok kontrol dengan rata-rata $60 \mathrm{mg} / \mathrm{dl}$ dan kelompok ALA dengan rata-rata $57,4 \mathrm{mg} / \mathrm{dl}$. Dari hasil uji statistik tersebut dapat ditarik kesimpulan bahwa ALA dapat mempertahankan kadar kolesterol total pada tikus DM sama seperti dalam keadaan normal.

Hasil penelitian ini sesuai dengan hasil beberapa penelitian lain yang menggunakan tikus DM untuk melihat pengaruh ALA terhadap komplikasi DM berupa hiperkolesterolemia seperti penelitian Maeda dan Xianwen tahun 2006 pada tikus yang diinduksi DM diberikan ALA selama 20 minggu menunjukkan bahwa ALA mencegah peningkatan kadar kolesterol total tikus sehingga mencegah terbentuknya aterosklerosis $^{10}$ dan penelitian Ghelani dkk tahun 2017 pada tikus DM tipe 2 yang diberika ALA selama 8 minggu menunjukkan perbedaan yang signifikan pada kadar kolesterol total antara kelompok ALA dan kelompok DM. ${ }^{11}$

Penelitian farmakologi untuk komplikasi DM tipe 2 telah banyak diteliti, salah satunya adalah tentang efek ALA dalam menurunkan kadar kolesterol total. Dari berbagai penelitian yang dilakukan ditemukan beberapa mekanisme ALA dapat menurunkan kadar kolesterol total. Pertama, ALA dapat menurunkan aktivitas HMG Ko-A reduktase yang berperan penting dalam biosintesis kolesterol sehingga menyebabkan sintesis kolesterol dari hati menurun. Kedua, ALA dapat meningkatkan reseptor LDL dihati sehingga meningkatkan pengambilan kolesterol LDL oleh hati. ${ }^{21}$ Ketiga, ALA dapat meningkatkan aktivitas LPL sehingga menurunkan produksi kolesterol VLDL.Keempat, ALA dapat menurunkan lipogenesis di hati dengan menurunkan ekspersi gen lipogenik seperti ChREBP dan SREBP-1C. Kelima, ALA dapat meningkatkan aktivitas LCAT yang berperan dalam esterifikasi kolesterol dari jaringan yang akan diangkut oleh HDL sehingga meningkatkan pengambilan kolesterol kehati melalui pertukaran HDL dan VLDL. Keenam, ALA dapat menurunkan kadar kolesterol dengan mengaktivasi SIRT1 dan AMPK yang meregulasi acetyl-CoA carboxylase (ACC); adipose triacylglycerol lipase (ATGL) dan fatty acid synthase (FAS). ${ }^{11}$ Ketujuh, ALA dapat meningkatkan ekspresi Apo-A yang akan meningkatkan pengangkutan kolesterol dari jaringan ke hati melalui jalur reverse cholesterol transport oleh HDL. ${ }^{22}$

Pencegahan ALA pada pembentukan lesi aterosklerosis selain melalui jalur kolesterol juga dikarenakan aktivitas ALA sebagai antioksidan. Pada penelitian sebelumnya, Ismawati dkk tahun 2011 membuktikan bahwa ALA mampu mencegah pembentukan lesi aterosklerosis pada aorta mencit diabetes yang diberi diet tinggi kolesterol. ${ }^{21}$ Penelitian Ismawati dkk tahun 2017 juga membuktikan ALA 
mampu mencegah pembentukan lesi aterosklerosis pada aorta abdominalis tikus yang sama pada penelitian ini. ${ }^{20} \mathrm{Hal}$ ini membuktikan bahwa ALA berpotensi untuk mencegah komplikasi dari diabetes melitus terutama PJK dari berbagai jalur metabolisme sehingga memungkinkan untuk dapat menurunkan angka kematian pasien DM akibat PJK.

\section{SIMPULAN DAN SARAN}

Berdasarkan hasil penelitian ini dapat disimpulkan bahwa asam alfa lipoat dapat mencegah terjadinya hiperkolesterolemia pada tikus DM tipe 2. Diharapkan dilakukan penelitian lebih lanjut untuk menganalisis lama pemberian ALA yang aman dan efektif pada pasien DM dengan komplikasi hiperkolesterolemia dan dilakukan penelitian pada manusia untuk keamanan dan efek samping yang timbul pada manusia dari pemberian ALA

\section{UCAPAN TERIMAKASIH}

Penulis mengucapkan terimakasih kepada LPPM Universitas Riau dan UPPM Fakultas Kedokteran Universitas Riau yang mendanai penelitian ini. Penulis juga mengucapkan terimakasih kepada semua pihak yang telah membantu dalam menyelesaikan penelitian ini.

\section{DAFTAR PUSTAKA}

1. Zimmet PZ, Alberti KGMM. Epidemology of diabetes-status of a pandemic and issue around metabolic surgery. Diabetes Care. 2016;39(6): 878-883.

2. Badan Penelitian dan Pengembangan Kesehatan Kementrian Kesehatan RI. Riset Kesehatan Dasar. 2013.

3. Tarigan TJE, Yunir E, Subekti I, Pramono LA, Martina D. Profile and analysis of diabetic chronic complications in outpatient Diabetes Clinic of Cipto Mangunkusumo Hospital Jakarta. Med J Indones. 2015;24:156-62.

4. Schteingart DE. Pankreas: Metabolisme glukosa dan diabetes mellitus. In: Price SA, Wilson LM, editors. Patofisiologi Sylvia $6^{\text {th }}$ ed. Indonesia: EGC; 2014. p. 1268-72.
5. Rao LN, Ponnusamy T, Philip S, Mokhopadhyay R, Kakkar VV, Mundkur L. Hypercholesterolemia induced immune respons and inflamation on progression of atherosclerosis in $A_{p o b^{t m 2 S g y}} L d l r^{t m 1 H e r} / \mathrm{J}$ mice. Lipid. 2015;50:785-95.

6. Libby P. The pathogenesis, prevention and treatment of atherosclerosis. In: Kasper DL, et al, editors. Harrison's Principles of Internal Medicine. $19^{\text {th }}$ ed. Newyork: Mc Graw Hill Education; 2012. p. 1578-92.

7. Giugliano D, Cariello A, Paolisso G. Oxidative stress and diabetic vaskular complications. Diabetes Care. 1996;19(3):257.

8. Soewondo P, Soegondo S, Suastika K, Pranoto A, Soetmadji DW, Tjokroprawiro A. The Diabcare Asia 2008 study-Outcomes on control and complications of type 2 diabetic patients in Indonesia. Med J Indones. 2010;19(4):235-44.

9. Soegondo S. Farmakoterapi pada pengendalian glikemia Diabetes Melitus Tipe 2. In: Sudoyo AW, et al, editors. Buku Ajar Ilmu Penyakit Dalam Jilid III $5^{\text {th }}$ ed. Indonesia: Interna Publishing; 2008. p. $1884-90$.

10. Maeda N, Yi X. á-Lipoic acid prevents the increase in atherosclerosis induce by diabetes in apolipoprotein E-deficient mice fed. High-fat/lowcholesterol diet. Diabetes. 2006;55:2238-44.

11. Ghelani H, Ramovski-Naumovski V, Nammi S. Chronic treatment of (R)-a-lipoic acid reduces blood glucose and lipid levels in high-fat diet and low-dose streptozotocin-induced metabolic syndrome and type 2 diabetes in Sprague-Dawley rats. Pharma Res and Per.2017;5(3):1-12

12. Salama RHM. Hypoglicemic effect of lipoic acid, carnitine and Nigella Sativa in diabetic rat model. Int J Health Sci. 2011;5(2):126-134.

13. Annadurai T, Muralidharan AR, Joseph T, Hsu MJ, Thomas PA, Geraldine P. Antihyperglicemic and antioxidant effect of a flavonone, naringenin, in streptozotocin-nicotinamide induced experimental diabetic rats. J Physiol Biochem. 2012;68:307-18.

14. Masiello P, et al. Experimental NIDDMdevelopment of a new model in adult 
rats administered streptozotocin and nicotinamide. Diabetes. 1998;47:224-229.

15.Szkudelski T. Streptozotocin-nicotinamideinduced diabetes in the rat. Characteristics of the experimental model. Exp Bio Med. 2012;237:481-90.

16. Ghasemi A, Khalifi S, Jedi S. Streptozotosinnikotinamid-induced rat model of type 2 diabetes(review). Acta Physiol Hung. 2014;101(4):408-420.

17. Rader DJ, Hobbs HH. Disorder of lipoprotein metabolism. In: Kasper DL, et al, editors. Harrison's Principles of Internal Medicine $19^{\text {th }}$ ed. Newyork: Mc Graw Hill Education; 2012. p.2435-49.

18. Murugan P, Parl L. Effect of tetrahydrocurcumin on lipid peroxidation and lipids in streptozotocinnicotinamide induced diabetic rats. Basic Clin Pharmacol Toxicol. 2006;99(2):122-7.
19. Satheesh MA, Pari L. Effect of pterostilbene on lipids and lipid profiles in streptozotocinnicotinamide induced type 2 diabetes mellitus. J Appl Biomed. 2008;6:31-7.

20.Ismawati, Sembiring LP. Pencegahan lesi aterosklerosis pada aorta abdominal oleh asam alfa lipoat pada tikus Diabetes Melitus Tipe 2. eJKI. Inpress.

21.Ismawati, Winarto, Sari RP. Pencegahan lesi aterosklerosis oleh asam alfa lipoat pada aorta mencit jantan (Mus Musculus) yang diberi diet tinggi kolesterol. Jurnal Ilmu Kedokteran. 2011;4:19-25.

22. Marangon K, Devaraj S, Tirosh O, Packer L, Jialal I. Comparison of the effect of alpha-lipoic acid and alpha-tocopherolsupplementation on measures of oxidative stress.Free Radic Biol Med.1999;27: 1114-1121. 